\title{
Predictors of Technology Integration Self-Efficacy Beliefs of Preservice Teachers
}

\author{
Salih Birisci \\ Uludag University, Turkey \\ Umit Kul \\ Artvin Coruh University, Turkey
}

\begin{abstract}
This correlational study aimed to investigate the prediction levels of technopedagogical education competency for technology integration self-efficacy beliefs of pre-service teachers. The study group comprised 174 pre-service teachers at the Faculty of Education of a university located in the Eastern Black Sea region of Turkey. Both "Technopedagogical Education Competency Scale" and "Technology Integration Self-Efficacy Perception Scale" were administered as data collection tools. The results of the study showed that pre-service teachers had high levels of technology integration self-efficacy beliefs, with a high-level positive correlation with technopedagogical education competency. In addition, the dimensions of technopedagogical education competency such as ethics, design, exertion and proficiency were revealed as the predictors of technology integration self-efficacy; moreover, predictive effects of exertion and proficiency dimensions are insignificant. The findings obtained from the present study are thought to be helpful for the development of pre-service teachers' technology integration self-efficacy beliefs.
\end{abstract}

Keywords: Technopedagogical education competency; Technology integration; Self-efficacy belief; Pre-service teachers

\section{Introduction}

The rapid increase in technological developments and their inclusion in all areas of life have become an expected situation. This situation makes the use of current technologies unavoidable in education activities (Mazman \& Usluel, 2011; Zhang \& Aikman, 2007). Within the scope of work to improve technological facilities in educational settings, teaching programs as well as learning-teaching processes should be revised within the context of developing technologies. Teachers' use of information and communication technologies in the learning and teaching process plays an important part of their duties and responsibilities. Hence, technological innovations form a situation that cannot be ignored during the development process of teachers. Within this aim, many organizations around the world are carrying out variety of technology-based projects to improve educational facilities (Topuz \& Goktas, 2015). In general these projects aimed not only to form information technology infrastructure for educational organizations but also to ensure integration of available technologies with teaching and learning activities. It is necessary for both teachers and pre-service teachers to monitor technological developments within the framework of project activities and have desired competencies to benefit from these in the context of educational activities. At this point both teachers and pre- 
service teachers have significant responsibilities as a practitioner. In order to form effective technological environments for courses, it is expected that both in-service teachers and preservice teachers have appropriate knowledge, beliefs and skills to take advantage of technology in teaching (Chen, Looi \& Chen, 2009). However, the integration of technology with teaching is a difficult, complicated and dynamic process (Binghimlas, 2009; Koehler, Mishra \& Yahya, 2007; Schoepp, 2005). Studies in the relevant literature have stated that successful results will not be obtained when technology integration process is not well conceptualized or assimilated by teachers (Ertmer, 2005; Hew \& Brush, 2007). As a result, an important element of teacher training programs is that pre-service teachers gain knowledge and skills about the use of new technologies within their professional development process (Chai et al., 2011).

The ability to use of technology is an important characteristic that all teachers should have (Ruggiero \& Mong, 2015). However, a range of elements in the form of prejudices, attitudes or experiences that may develop against these regulations may be effective on the inclusion of technological possibilities by present teachers and prospective teachers (Belland, 2009; Ertmer et al., 2012; Galvis, 2012; Kaya \& Yilayaz, 2013). Additionally, technology-related courses given with the aim of successful technology integration may be insufficient to prepare pre-service teachers (Karatas, 2014; Polly, Mims, Shepherd \& Inan, 2010). Besides, newly graduated preservice teachers are identified not to have sufficient skill levels to use computer technologies in educational processes (Kurz \& Middleton, 2006). According to the findings from a study by Smith and Shotsberger (2001), the majority of pre-service teachers stated that technology had an important role in education; however, they identified that some pre-service teachers were uncomfortable with discussing specific use of technology due to lack of knowledge. As a result, teacher education programs should focus on how to integrate technological knowledge with pedagogical and content knowledge (Hew \& Brush, 2007; Sweeney \& Drummond, 2013). In this context, there is a need for a conceptual framework for the effective use of technological developments by teachers within educational activities. According to the technological pedagogical content knowledge (TPCK) model, it is expected that educational technologies will be used properly within the framework of teaching and learning activities (Harris, Mishra \& Koehler, 2009; Kabakci-Yurdakul, 2011; Shin et al., 2009; Voogt \& McKenney, 2017).

The developed TPCK model emphasizes the importance and necessity of uniting technological, pedagogical and content knowledge of a teacher with an appropriate approach to effectively complete technology-supported teaching. This framework describes TPCK-based organization encompassing all stages of a lesson to ensure integration of teaching technologies with education (Kabakci-Yurdakul, 2011). Koehler and Mishra (2008) stated that the technological, pedagogical and content knowledge types included within the framework had a dynamic relationship, and that they should not be considered separate components. So, it appears that the technopedagogical education competency level of a teacher plays an important role during the application of the TPCK model. For teachers to have desired TPCK competency, they need to accurately adapt knowledge types in the model. That's why, it is necessary to research the required TPCK competency and their reflection levels among pre-service teachers.

Another important topic that must be mentioned is the teachers' self-efficacy beliefs about technology integration in education (Ertmer, 2005; Wang, Ertmer \& Newby, 2004). Bandura (1982) defined the self-efficacy concept as a personal assessment of what the individual can do when they encounter certain tasks. Stated differently, self-efficacy is the belief about organizing and applying necessary skills in order for a person to achieve desired results (Bandura, 1997; Skaalvik \& Skaalvik, 2010). It is possible to determine in advance what knowledge and skills they have, and what can be done in the class, by determining the self-efficacy beliefs possessed 
(Pajares, 1992). In the process of integrating appropriate information and communication opportunities, digital technologies are considered common assets in schools. This situation leads community to expect students to be instructed by technology-based education activities (Koc \& Bakir, 2012). Based on the self-efficacy theory, beliefs that teachers have in the way that they can accomplish may highlight the process of technology integration in education. It is possible to accept the self-efficacy beliefs of teachers in the context of technology integration is related to the necessity of including technological skills within the scope of educational activities (Albion, 1999; Chen, 2008; Ertmer, 2005; Ruggiero \& Mong, 2015; Teo, 2011).

Reflections of self-efficacy beliefs may be experienced during in-class applications by teachers. Teachers with strong self-efficacy beliefs may choose to use different teaching techniques, adopting a student-centered teaching approach; contrary to this, teachers with low self-efficacy beliefs were stated to have a more teacher-centered lesson tendency during in-class teaching (Henson, 2001; Milner \& Woolfolk-Hoy, 2002; Perkmen \& Pamuk, 2011). Thus, it is possible to say that technology integration self-efficacy beliefs may be a factor for a teacher diversifying inclass applications. In this context, to ensure the planned improvement by including technology within the education process, it is important that teachers have necessary competency about benefitting from these technologies (Coklar, Kilicer \& Odabasi, 2007).

In the relevant literature, it is possible to encounter research about identifying technology integration self-efficacy perceptions (Akgun, Ozgur \& Cuhadar, 2016; Bakac \& Ozen, 2017; Ceylan et al., 2014; ; Ersoy, Yurdakul \& Ceylan, 2016; Giles \& Kent, 2016; Han, Shin \& Ko, 2017; Ma \& Cavanagh, 2018; Raphael \& Mtebe, 2017; Sari et al., 2016; Sun, Strobel \& Newby, 2017; Yagci, 2016) and technopedagogical education competence levels of teachers and pre-service teachers (Agyei \& Voogt, 2015; Coklar, 2014; Kuskaya-Mumcu, Haslaman, \& Kocak-Usluel, 2008; Kabakci-Yurdakul et al. 2012; Redmond \& Lock, 2013). Similarly, there are studies investigating the correlations between these (Abbitt, 2011; Karatas \& Aslan-Tutak, 2017; Keser et al., 2015; Nathan, 2009; Unal, 2013).

The study by Keser et al. (2015) investigated the technology integration self-efficacy perceptions and technopedagogical education competency level of 713 pre-service teachers who are freshman and senior students according to the variables of gender, class level and program. According to the results of this study, the TPCK competency and self-efficacy perception about technology integration levels of pre-service teachers were identified to be high. Additionally, according to the class level of pre-service teachers, there was a statistically significant difference in technology integration self-efficacy beliefs; however, there was no statistically significant difference according to gender.

Similarly, the study by Abbitt (2011) provided training about the use of technology in education for 16 hours during a semester to 45 preschool pre-service teachers. According to the posttest results of the study, there was a significant correlation between the technology integration selfefficacy perceptions and TPCK knowledge components of teacher candidates. This study also stated that the efforts to develop TPCK knowledge among pre-service teachers was beneficial in increasing their self-efficacy perceptions.

Another study by Unal (2013) identified a significant, positive and high-level correlation between the technology integration self-efficacy perceptions with technopedagogical education competency according to the result of a study including 748 pre-service teachers attending different programs. Additionally, they found the subdimensions of technopedagogical education competency significantly predicted self-efficacy perceptions about technology integration. Also, 
Nathan (2009) found a positive moderate-level correlation between the self-efficacy perception related to technology integration and TPCK among pre-service teachers.

When pre-service teachers participating in the study by Kabakci-Yurdakul (2011) assessed themselves within the context of technopedagogical education competency, they stated that they were moderately competent only in the proficiency category of the subdimensions at advanced level. Additionally, as the levels of use related to information and communication technologies of pre-service teachers participating in the study increased, it was identified that the technopedagogical education competency increased.

Technology integration has an important role in learning and teaching processes. Considering the importance of technological competency in the field of information and communication technologies, increasing the technology integration self-efficacy beliefs of pre-service teachers is believed to be vital in shaping their education levels. Although many studies have been conducted for understanding pre-service teachers' technology integration, there are still some obstacles which affect pre-service teachers' technology integration self-efficacy beliefs in education. Abbitt (2011) stated that teachers' technological pedagogical content knowledge positively affects the technology integration. Therefore, the current study provides insight in better understanding the relationship between technology integration self-efficacy beliefs and technopedagogical education competencies in preparing teachers to integrate technology into teaching. From this point, the present study aimed to investigate technology integration selfefficacy belief levels of pre-service teachers. The following research questions have been sought:

1. What is the general level of technology integration self-efficacy beliefs of pre-service teachers?

2. Is technopedagogical education competency level of pre-service teachers a significant predictor of their technology integration self-efficacy beliefs?

\section{Methodology}

\section{Research Model}

In this study, technology integration self-efficacy levels of pre-service teachers were investigated by adopting a correlational study model. The correlational study is a research model aiming to determine whether there is a relationship between two or more variables and/or to determine the degree of the relationship (Creswell, 2012; Fraenkel \& Wallen, 2006).

\section{Participants and Procedures}

The participants of the current research comprised 186 pre-service teachers enrolled at pedagogical formation education program at the education faculty of a state university in Turkey in the spring semester of the 2016-2017. However, 12 participants were not included in the data analysis process due to missing data. Eventually, 174 pre-service teachers comprised the sample of the study. Accordingly, 108 female (62\%) and 66 male (38\%) participants were included in the research process. The ages of the pre-service teachers ranged from 21 to 25 and the majority of them were at the age limit of $23(32 \%)$. The distribution of pre-service teachers according to their department ranged as $142(82 \%)$ social sciences, $25(14 \%)$ science, and $7(4 \%)$ health sciences. 
Convenience sampling was used for the selection of participants. The fact that the researchers were working at the faculty where pre-service teachers participated in the sample were studying was effective on determining and reaching the sample. The pre-service teachers who participated in the research process were given importance to have successfully completed the courses as "Instructional Technologies and Material Design", "Teaching Principles and Methods", "Special Teaching Methods" and "Teaching Experience" during their educational process. Regarding the ethical issues, all the necessary permissions were obtained from the faculty administration and the participants were informed prior to study and anonymity of them was respected. The questionnaires were administered to participant in the classroom setting which took 10-15 minutes to complete as a paper-pencil based format. No names or personal information were requested from them.

\section{Data Collection Tools}

Personal Information Form: This simple form included three questions to reveal demographic characteristics of participants as gender, age and graduation type.

Technopedagogical Education Competency (TPACK-deep) Scale: The Technopedagogical Education Competency Scale was developed by Kabakci-Yurdakul et al. (2012) that include 33 items. This scale consists of four sub-dimensions: Design (e.g., "I can organize the educational environment in an appropriate way to use technology"), Exertion (e.g., "I can assess whether students have the appropriate content knowledge by using technology"), Ethics (e.g., "I can provide guidance to students by leading them to valid and reliable digital sources"), and Proficiency (e.g., "I can become a leader in spreading the use of technological innovations in my future teaching community"). The scale does not contain any negative items and were rated on a 5-point Likert scale $(1=$ I definitely can't do it , $2=I$ can't do it , $3=$ I can partly do it, $4=$ I can do it, $5=1$ can easily do it ). Higher scores indicate more Technopedagogical education competency. Confirmatory factor analysis of TPACK-Deep scale showed that it was well fit with following indices; GFI $=.94, \mathrm{AGFI}=.89, \mathrm{SRMR}=.048, \mathrm{NNFI}=.91, \mathrm{CFI}=.95, \mathrm{RMSEA}=.078$. . The reliability of the scale is acceptable and Cronbach's alpha for TPACK-Deep was .95 (KabakciYurdakul et al., 2012). The Cronbach's alpha internal consistency coefficient was calculated as .94 during application of the scale to the sample group in this study.

Technology Integration Self-Efficacy Scale (TISES): The Technology Integration Self-Efficacy Scale was developed by Wang (2004). The Turkish version of TISES was adopted by Unal (2013) which consists of 19 items with two sub-dimensions: Use of computer technologies self-efficacy (e.g., "I believe that I have the skills to use computers for teaching purposes") and Making others use computer technology self-efficacy (e.g., I believe that I can give individual feedback to my students when they use technology"). The two factors of the scale explained $53 \%$ of the total variance. All the items in the scale were stated positively and there were coded reversely. Participants rated on a 5-point Likert scale ( 1 = Definitely disagree, $2=$ Disagree, $3=$ Neutral, $4=$ Agree, 5 = Definitely agree). Higher scores indicate more technology integration self-efficacy. Confirmatory factor analysis of the Turkish version of the scale showed that the TISES was well fit with following fit indices; GFI $=.93, \mathrm{AGFI}=.92, \mathrm{RMR}=.034, \mathrm{NNFI}=.98, \mathrm{CFI}=.99, \mathrm{RMSEA}=$ .056. The reliability of the scale is acceptable and Cronbach's alpha for TISES was .93 (Unal, 2013). The Cronbach's alpha internal consistency coefficient was calculated as .94 during application of the scale to the sample group in the current study. 


\section{Data Analysis}

While answering the first research question, the mean and standard deviation of the total scores from the Technology Integration Self-efficacy Perception scale of pre-service teachers was calculated and the results were used to determine the technology integration self-efficacy levels according to criteria stated by Unal (2013). The following interpretations can be made about self-efficacy levels; if total points obtained from the scale in general are below 48 , self-efficacy is perceived as low; if points are from 48-66, self-efficacy is undecided and if above 66 , it is perceived as high.

For the second research question, the stepwise regression analysis was used to investigate whether sub-dimensions of technopedagogical education competency were significant predictors of the technology integration self-efficacy levels of pre-service teachers. To perform stepwise regression analysis, assumptions of the multiple regression analyses were checked. For this, normality of data examined by skewness and kurtosis values. Skewness values ranged from -.76 to .07 and Kurtosis values ranged from -.27 to .86 , based on these values data could be acceptable as normal distribution. Accordingly, the tolerance values of the final model of stepwise regression determining technopedagogical education competency scale subdimensions were .29 for ethics, .34 for design, .29 for exertion and .38 for proficiency. These tolerance values are not close to zero and are not smaller than .10 which means they are acceptable. When the VIF values were examined for correlation investigations, it is necessary that this value be smaller than 10 (Tabachnick \& Fidell, 2001). The VIF values for the final model of stepwise regression analysis in this study were ranged 2.6 to 3.6 which indicated that there was no multicollinearity. These analyses were carried out through SPSS 20.0 version.

\section{Findings}

In this section, the findings revealed by analysis of data are presented. First, an attempt is made to determine the technology integration self-efficacy belief levels of pre-service teachers. Then, the results of stepwise regression regarding whether the technopedagogical competency levels of pre-service teachers are significant predictors of technology integration self-efficacy beliefs are presented.

\section{Technology Integration Self-efficacy of Pre-Service Teachers}

The descriptive statistical values related to points obtained in general and from sub-dimensions of the Technology Integration Self-efficacy scale by participants are given in Table 1.

Table 1. Descriptive Statistics Related to Technology Integration Self-Efficacy of Pre-Service Teachers

\begin{tabular}{lccccc}
\hline Subdimensions & Items & Min Score & Max Score & Mean & SD \\
\hline $\begin{array}{l}\text { Use of computer technologies self- } \\
\text { efficacy }\end{array}$ & 6 & 12 & 30 & 22.9 & 3.9 \\
$\begin{array}{l}\text { Making others use computer } \\
\text { technologies self-efficacy }\end{array}$ & 13 & 23 & 65 & 51.02 & 8.04 \\
\hline Total & 19 & 45 & 95 & 74 & 11.3 \\
\hline
\end{tabular}


According to the findings in Table 1, the minimum score obtained by the participants from the technology integration self-efficacy scale was 45 and the maximum score was 95 . The mean of general score obtained from the scale was calculated as 74 . Bearing in mind the score values that can be obtained from the scale in general, the technology integration self-efficacy scores obtained by the participants in the current study may be considered high.

\section{Predictors of Technology Integration Self-Efficacy}

For the second research question, the stepwise regression analysis was applied to test whether the sub-dimension levels of the technopedagogical education competency scale were significant predictors of the technology integration self-efficacy levels. Before completing the stepwise regression analysis, the Pearson Moments Multiplication Correlation analysis was applied to investigate the correlations between the variables. The correlation coefficients and descriptive statistical values showing the correlations between variables are presented in Table 2 .

Table 2. Descriptive Statistics and Pearson Correlation Coefficients between variables

\begin{tabular}{llllll}
\hline & TISE & Design & Exertion & Ethics & Proficiency \\
TISE & - & & & \\
Design & $.67^{*}$ & - & & & \\
Exertion & $.63^{*}$ & $.76^{*}$ & - & & \\
Ethics & $.69^{*}$ & $.75^{*}$ & $.81^{*}$ & - & \\
Proficiency & $.62^{*}$ & $.71^{*}$ & $.72^{*}$ & $.74^{*}$ & - \\
\hline Mean & 74 & 39.7 & 46.1 & 22.4 & 19.9 \\
SD & 11.4 & 5.0 & 7.9 & 4.1 & 3.7 \\
Skewness & -.38 & -.25 & .07 & -.17 & -.76 \\
Kurtosis & .03 & -.27 & .66 & -.3 & .86 \\
\hline
\end{tabular}

Notes. ${ }^{*} p<.05 ;$ TISE: Technology Integration Self-efficacy

As seen in Table 2, there were positive and high correlations between technology integration self-efficacy perception with design $\left(r_{(174)}=.67, p<.05\right)$, exertion $\left(r_{(174)}=.63, p<.05\right)$, ethics $\left(r_{(174)}=.69, p<.05\right)$, and proficiency $\left(r_{(174)}=.62, p<.05\right)$ dimensions. Again, as seen in Table 2 , when the total mean points for technopedagogical education competency were investigated in terms of subdimensions, it was revealed that students considered themselves to be competent at advanced levels for design $(M=39.7, S D=5.0)$, exertion $(M=46.1, S D=7.9)$, ethics $(M=22.4$, $S D=4.1)$, and proficiency $(M=19.9, S D=3.7)$. In other words, pre-service teachers thought that they had advanced levels of technopedagogical education competency.

With the aim of determining which of the independent variables dealt with in the study provided a significant contribution to predicting technology integration self-efficacy perception levels, the stepwise regression method was applied. The variables contributing significantly to predicting technology self-efficacy perception levels and the contribution of these variables to the total 
variance in predicting technology integration self-efficacy from the stepwise regression method are shown in Table 3.

Table 3. Stepwise Regression Analysis Results for Predictors of Technology Integration SelfEfficacy

\begin{tabular}{llllllllll}
\hline Model & Variables & $\mathrm{B}$ & $\mathrm{SE}$ & $\beta$ & $\mathrm{t}$ & $\mathrm{R}^{2}$ & $\operatorname{Adj~} \mathrm{R}^{2}$ & $\Delta \mathrm{R}$ & $\mathrm{F}$ \\
\hline 1 & Ethics & 1.92 & .15 & .67 & $8.84^{*}$ & .47 & .47 & .47 & $155.67^{*}$ \\
\hline 2 & Ethics & 1.18 & .22 & .43 & $5.31^{*}$ & \multirow{2}{*}{.32} & \multirow{2}{*}{.523} & .05 & \multirow{2}{*}{$95.73^{*}$} \\
\hline & Design & .67 & .15 & .35 & $4.39^{*}$ & .52 & & & \\
& Ethics & 1.05 & .27 & .38 & $3.96^{*}$ & & & & \\
& Design & .61 & .17 & .32 & $3.69^{*}$ & .53 & .522 & .002 & $64.03^{*}$ \\
& Exertion & .12 & .14 & .09 & .91 & & & & \\
\hline 4 & Ethics & .92 & .27 & .33 & $3.32^{*}$ & & & & \\
& Design & .54 & .17 & .28 & $3.14^{*}$ & & & & \\
& Exertion & .08 & .14 & .05 & .56 & .54 & .527 & .008 & $49.25^{*}$ \\
& Proficiency & .44 & .26 & .14 & 1.68 & & & & \\
\hline
\end{tabular}

Notes: ${ }^{*} p<.05$

The results of the stepwise multiple regression analysis related to prediction of technology integration efficacy scores of pre-service teachers and the regression model was determined to be significant $\left(\mathrm{F}_{(1,169)}=49.25, \mathrm{p}<.001\right)$. Accordingly, apart from the exertion and proficiency dimensions, the ethics and design variables explained $52 \%$ of the total variance $\left(R^{2}=.54\right.$, corrected $\left.R^{2}=.527\right)$. In the first stage, ethics entered to equation and it explained $47 \%$ of the total variance alone $\left(R^{2}=.47\right)$. Then, design entered on the second step in addition to the ethics. The additional contribution of the design was $5 \%$ and the ethics and design variables together increased explanation of total variance of technology integration self-efficacy points to $52.3 \%$ $\left(R^{2}=.52, \Delta R^{2}=.05\right.$, Adj $\left.R^{2}=.52\right)$. Moreover, exertion entered on the third step in addition to the ethics and design; however, this variable was not observed to contribute significantly. Finally, proficiency entered on the fourth step and this variable was identified not to contribute significantly either. However, both exertion and proficiency have still barely impact on $\mathrm{F}$ values to reduce. Final stepwise regression model with smallest $F$ value $(F=49.25)$ is investigated in detail, it was revealed that the ethics $(\beta=.33, p<.01)$, design $(\beta=.28, p<.01)$ variables significantly predicted technology integration self-efficacy but exertion $(\beta=.05, p>.05)$, and proficiency $(\beta=.14, p>.05)$ variables are not significantly predicted technology integration selfefficacy.

Among all these variables, ethics was the variable that predicted technology integration selfefficacy most. Accordingly, with the increase in the dimension levels of technopedagogical education competency in the order of ethics, design, exertion and proficiency, the technology integration self-efficacy levels of pre-service teachers increased.

\section{Discussion and Conclusion}

In this study, it is aimed to examine the predictors of technology integration self-efficacy beliefs of the pre-service teachers who have received pedagogical formation education. With this aim, first a general assessment related to technology integration self-efficacy beliefs of pre-service teachers were completed. As a result of the findings, pre-service teachers had high levels of 
technology integration self-efficacy beliefs that makes it necessary to investigate what may have caused this situation.

Experiences in the context of technology-based course may be shown as one of the causes of high technology integration self-efficacy beliefs of the participants. A study by Arslan (2012) showed that the most important predictor of students' self-efficacy beliefs is linked to their achievement within own experiences. Giles and Kent (2016) reported that majority of preservice teachers have high level confidence in their ability to select and utilize technology in teaching experiences. Based on these results one can claim that that personal behaviors have an effect on self-efficacy, and this situation may be linked to source of self-efficacy as mastery experience (Bandura, 1995). According to Pajares (2002), mastery experiences are vital for selfefficacy beliefs. Kiili, Kauppinen, Coiro, and Utriainen (2016) stressed the importance of feeling self-confidence in technology integration and stated that this can be achieved by provision of hands-on engagement with technologies. In addition to this, the intense use of computer, internet and mobile applications under current conditions is considered to be an important factor in the development of technological self-efficacy levels.

John (2013) suggested that available computer knowledge in addition to previous computer experiences significantly affected technology self-efficacy. However, Ritzhaupt, Dawson, and Cavanaugh (2012) showed that in addition to a tendency to use technology, experiences in this field were also factors affecting the integration of technology into educational environments. In fact, among questions related to "computer use" sub-dimension of the technology integration self-efficacy belief scale, the pre-service teachers had similar high levels to the technology integration self-efficacy beliefs which may be linked to the students' previous experiences. Participants in this study attended to the Instructional Technologies and Material Design (ITMD) course during pedagogical formation education. The gaining of technological competency and practical experience in these courses may be reflected in the positive outcomes of teacher candidates. The importance of the ITMD course has been emphasized in many studies and it is stated to contribute to professional development of pre-service teachers by forming an effective learning-teaching process integrating technology with lesson content (Akinci, 2017; Gecer, 2010; Gokdas \& Torun, 2017; Gunduz \& Odabasi, 2004; Yazar, 2015). Ijpek and Acuner (2011) stated that the computer self-efficacy beliefs may be estimated from attitudes of pre-service teachers to education technologies. If this situation is dealt with in the form of technology integration self-efficacy, there is a direct proportional correlation between previous computer experience and technology integration self-efficacy which has been revealed by many researchers (Anderson \& Maninger, 2007; Lemon \& Garvis, 2016; Raphael \& Mtebe, 2017; Teo, 2009).

Within the framework of the second research question, the correlation between the technology integration self-efficacy beliefs and technopedagogical education competency of pre-service teachers and the predictive power of relevant competency dimensions for technology integration self-efficacy beliefs were investigated. First, the correlation levels between technology integration self-efficacy belief and technopedagogical education competency dimensions were dealt with within the framework of the TPCK conceptual construct (Mishra \& Koehler, 2006). Among the findings obtained within this scope, it was concluded that there was a positive and high-level correlation between the TPCK competency levels and technology integration self-efficacy beliefs. This situation may be stated as an increase in occurring technopedagogical education competency leading to an increase in technology self-efficacy belief levels. Similarly, studies in the literature have revealed a significant correlation between technology self-efficacy and TPCK levels (Abitt, 2011; Keser et al., 2015; Unal, 2013; Vargas et al., 2017). Kabakci-Yurdakul (2011) studied the competency levels related to technopedagogical 
education of pre-service teachers and how these levels differed in terms of information and communication technologies and concluded that as the level of use of ICTs among pre-service teachers and technopedagogical education competency level were increased. Lee and Tsai (2010) also stated that teachers with sufficient TPCK competency lead them to integrate technology effectively into their education activities. Angeli and Valanides (2009), working on technology education within the teacher training process, stated that after education within the scope of teaching technology content courses in the first years of the learning process development was observed in the TPCK competency of teachers. Incik and Akay (2017) also indicated positive correlation between pre-service teachers' technopedogogical educational competency and perception towards technology. Researchers suggested that TPCK framework provides a structure for understanding how technology integration takes place (Abbitt, 2011; Colvin \& Tomayko, 2015; DeSantis, 2016; Keser, Yılmaz \& Yılmaz, 2015)

After determining a meaningful correlation between technopedagogical education competency and technology integration self-efficacy belief levels, prediction levels of the relevant subdimensions for technology integration self-efficacy beliefs were examined. It was determined that all the dimensions of technopedagogical education competency were significant predictors of technology integration self-efficacy beliefs. The strongest factor predicting technology integration self-efficacy beliefs of the participants was the ethics dimension. The availability of technology brings challenging issues in today and It is important to have responsibilities that all teachers should be aware of them. The ethics dimension is explained as awareness levels about the accuracy, privacy, access and intellectual property aspects of knowledge along with competency required for professional ethics of teaching among TPCK competency (KabakciYurdakul et al., 2012). Additionally, the importance of the ethics concept within technological knowledge concept of professional standards for teachers has been emphasized in many programs (ISTE, 2008; MEB, 2017).

There is a variety of studies dealing with the moral factors among technology integration in education (Lucey \& Grant, 2009; Mayes, Natividad \& Spector, 2015; Shin, 2015). In such studies it is highlighted that ethical factors may put educational technologist at risk while supporting organizations' educational goals (Lucey \& Grant, 2009; Mayes, Natividad \& Spector, 2015). Among these, the studies with descriptive aims identified the highest levels for the ethics dimension among technopedogogical competencies (Albayrak-Sarı et al., 2016; Yorulmaz, Can \& Çokcaliskan, 2017; Kabakci-Yurdakul, 2011; Keser et al., 2015). Unal (2013) concluded that the ethics was the primary dimension among technopedagogical education competency predicting technology integration self-efficacy perception of pre-service teachers. In general, the studies in the literature have shown similar results with the current study that pre-service teachers are aware of the importance of ethical values in the process of technology integration in education. This situation is considered to be an important concept in emphasizing the importance of the ethics in technology integration process.

After the ethics, the other factors predicting technology integration self-efficacy beliefs of preservice teachers was determined as the design dimension. As known, teachers benefit from technological opportunities in the knowledge configuration stage during their teaching process. This situation is also valid for the design of teaching materials and their application. In this situation if the design dimension among competencies is considered appropriately to organize technological possibilities in the teaching-learning process (Kabakci-Yurdakul et al., 2012), their adaptation to technology integration self-efficacy becomes undeniable. In other words, the results of this study showed that pre-service teachers are aware of the importance of benefiting from technological opportunities in the design process of educational activities. This result is 
similar to the results of other studies in the literature. Abbitt (2011) in a study of pre-service teachers showed that technological pedagogical knowledge was among variables predicting technology integration self-efficacy. Bakac and Ozen (2017) concluded that there was an increase in instructional technology and material design self-efficacy belief levels linked to TPCK competency. In this situation, the TPCK-based lesson design process was a significant factor in the development of TPCK competency (Gokdas \& Torun, 2017; Jang \& Chen, 2010).

The exertion and proficiency dimensions among TPCK competencies were among the predictors of technology integration self-efficacy; however, they were determined not to contribute significantly to the prediction of self-efficacy beliefs. The exertion and proficiency dimensions dealt with guidance activities completing instructional activities by teachers and pre-service teachers. Among reasons for ineffectiveness of these dimensions in predicting technology integration self-efficacy is the lack of effectiveness of competencies reflected in the application process of planned technological activities during pedagogical formation education process. The reason for this is the lack of integration of theoretical knowledge along with technological skills related to applications during lessons in the teacher education process which may be shown as a problem affecting development of TPCK levels among pre-service teachers. This situation in teacher education has been emphasized in a variety of studies in the literature (Aslan \& Zhu, 2015; Chai \& Koh, 2017; Hiebert, Morris, Berk \& Jansen, 2007; Hollins, Luna \& Lopez, 2014; Kaya \& Yilayaz, 2013; Tanak, in press).

In other words, lack of teaching experiences in real classroom environments may be a barrier for pre-service teachers to integrate technology into teaching (Chai, Koh \& Tsai, 2010; Flick \& Bell, 2000; Kay, 2006). It would not be wrong to talk about technology integration in education for inexperienced teacher candidates (Kovalik, Kuo, \& Karpinski, 2013). Therefore, gaining technology integration self-efficacy beliefs together with the transfer of TPCK competencies to a real class environment would overcome the problem by providing intensive microteaching experiences in the teacher education (Akkoc, 2011; Canbazoğlu-Bilici \& Yamak, 2014; Cavin, 2008; Durdu \& Dag, 2017; Hoffer \& Grandgenett, 2012; Lee \& Lee, 2014; Parsons \& Stephanson, 2005; Sun, Strobel \& Newby, 2017).

In conclusion, an increase was observed in technology integration self-efficacy beliefs linked to the increase in technopedagogical education competency of pedagogical formation students. It was found that among the technopedagogical education competencies, the ethics and design dimensions were at the forefront of predicting technology integration self-efficacy beliefs with no significant contribution of exertion and proficiency dimensions. This situation suggests the capability of students linked to technological competencies obtained during the learning process revealing the limitations of beliefs related to inclusion of these competencies in real classroom environments. Therefore, for the development of technology integration self-efficacy beliefs, necessary and appropriate education should be provided by analyzing the roles in interaction of self-efficacy beliefs.

\section{Limitations and Recommendations}

The results of this study need to be considered in the light of its limitations. It is considered that the results will contribute to scientific studies about the educational process of teacher training in general and pedagogical formation education in particular, and it is recommended the study would be replicated with sample groups including larger participants from other branches in education. The data were collected with the Technology Integration Self-Efficacy Belief adapted 
to Turkish (Unal, 2013) and the Technopedagogical Education Competency (Kabakci-Yurdakul, 2012) scales. Comparison of the research results with data obtained with different scales and methods will ensure the ability to generalize the results better. This study relied on pre-service teachers' self-reported data. Future studies may employ mixed research strategies that include interviews and observations to gather more data about technology integration self-efficacy of pre-service teachers while integrating technology into their teaching practices

\section{Acknowledgements}

An earlier version of this paper was presented at the $8^{\text {th }}$ International Congress of Research in Education, May 9-11, 2018, Manisa, Turkey.

\section{References}

Abbitt, J. T. (2011). An investigation of the relationship between self-efficacy beliefs about technology integration and technological pedagogical content knowledge (TPACK) among preservice teachers. Journal of Digital Learning in Teacher Education, 27 (4), 134143.

Akgun, F., Ozgur, H., \& Cuhadar, C. (2016). The investigation of technopedagogical knowledge competencies of teacher candidates and pedagogical formation students. Adiyaman University Journal of Social Sciences, 8(24), 837-872.

Akkoc, H. (2011). Investigating the development of prospective mathematics teachers' technological pedagogical content knowledge. Research in Mathematics Education, 13(1), 75-76. doi:10.1080/14794802.2011.550729

Akinci, M. (2017). English teacher candidates' self-efficacy towards FATIH project. Dicle University Journal of Ziya Gokalp Faculty of Education, 30, 543-555. http://dx.doi.org/ 10.14582/DUZGEF.1802

Albayrak-Sari, A., Canbazoglu-Bilici, S., Baran, E., \& Ozbay, U. (2016). Investigating the relationship between teachers' technological pedagogical content knowledge (TPACK) competencies and attitudes towards information and communication technologies. Educational Technology Theory and Practice, 6(1), 1-21.

Albion, P. (1999). Self-efficacy beliefs as an indicator of teachers' preparedness for teaching with technology. Paper presented in Proceedings of the 10th International Conference of the Society for Information Technology \& Teacher Education (pp. 1602- 1608), Austin, Texas: Association for the Advancement of Computing in Education.

Anderson, S. \& Maninger, R. (2007). Preservice teachers' abilities, beliefs, and intentions regarding technology integration. Journal of Educational Computing Research, 37, 151172.

Angeli, C. \& Valanides, N. (2009). Epistemological and methodological issues for the conceptualization, development, and assessment of ICT-TPCK: Advances in technological pedagogical content knowledge (TPCK). Computers \& Education, 52(1), 154-168. http://dx.doi.org/10.1016/j.compedu.2008.07.006 
Arslan, A. (2012). Predictive power of the sources of primary school students' self-efficacy beliefs on their self-efficacy beliefs for learning and performance. Educational Sciences: Theory \& Practice, 12(3), 1907-1920.

Aslan, A. \& Zhu, C. (2015). Pre-service teachers' perceptions of ICT integration in teacher education in turkey. The Turkish Online Journal of Educational Technology, 4(3), 97-110.

Ay, Y. (2015). Evaluation of teachers' technological pedagogical content knowledge (tpack) within the framework of practical model (Unpublished doctoral dissertation). Osmangazi University, Eskisehir.

Bakac, E. \& Ozen, R. (2017). Examining preservice teachers' material design self-efficacy beliefs based on their technological pedagogical content knowledge competencies. Ahi Evran University Journal of Education, 18(2), 613-632.

Bandura, A. (1982). Self-efficacy mechanism in human agency. American Psychologist, 37(2), 122-147.

Bandura, A. (1995). Self-efficacy in changing societies. New York: Cambridge University Press.

Bandura, A. (1997). Self-efficacy: The exercise of control. New York: W. H. Freeman and Company.

Belland, B. R. (2009). Using the theory of habitus to move beyond the study of barriers to technology integration. Computers \& Education, 52(2), 353-364.

Binghimlas, K. A. (2009). Barriers to the successful integration of ICT in teaching and learning: A review of literature. Eurasia Journal of Mathematics, Science and Technology Education, 5(3), 235-245.

Canbazogl-Bilici, S. \& Yamak, H. (2014). Pre-Service Teachers' Opinions about Microteaching in a Tpack-Based Research. Mehmet Akif Ersoy University Journal of Education, 32, 40-61.

Cavin, R. (2008). Developing technological pedagogical content knowledge in preservice teachers through microteaching lesson study. In K. McFerrin et al. (Eds.), Proceedings of Society for Information Technology and Teacher Education International Conference (pp. 5214-5220). Chesapeake, VA: AACE.

Ceylan, B., Turk, M., Yaman, F., \& Kabakci-Yurdakul, I. (2014). Determining the changes of information and communication technology guidance teacher candidates' technological pedagogical content knowledge competency, information and communication technology usage phases and levels. Journal of Theory and Practice in Education, 10(1), 171-201.

Chai, C.S., Koh, J.H.L., \& Tsai, C.C. (2010). Facilitating preservice teachers' development of technological, pedagogical, and content knowledge (TPACK). Educational Technology \& Society, 13, 63-73

Chai, C.S., Koh, J.H.L., Tsai, C.C. \& L.L.W. Tan. (2011). Modeling primary school pre-service teachers' technological pedagogical content knowledge (TPACK) for meaningful learning with information and communication technology (ICT). Computers \& Education, 57, 1184-1193.

Chai, C. S. \& Koh, J. H. L. (2017) Changing teachers' TPACK and design beliefs through the Scaffolded TPACK Lesson Design Model (STLDM). Learning: Research and Practice, 3(2), 114-129. http://dx.doi.org/10.1080/23735082.2017.1360506 
Chen, Y. (2008). A mixed-method study of EFL teachers' internet use in language instruction. Teaching and Teacher Education, 24, 1015-1028.

Chen, F., Looi, C., \& Chen, W. (2009). Integrating technology in the classroom: A visual conceptualization of teachers' knowledge, goals and beliefs. Journal of Computer Assisted Learning, 25(5), 470-488.

Coklar A.N., Kilicer, K. \& Odabasi, H.F. (2007). A critical overview of technology use in education: Technopedagogy. Proceedings of $7^{\text {th }}$ International Educational Technology Conference, (pp. 39-44). Nicosia, Cyprus: Near East University.

Colvin, J. C. \& Tomayko, M. C. (2015). Putting TPACK on the radar: A visual quantitative model for tracking growth of essential teacher knowledge. Contemporary Issues in Technology and Teacher Education, 15(1), 68-84.

Creswell, J. W. (2012). Educational research: Planning, conducting, and evaluating quantitative and qualitative research (4th ed.). Boston, MA: Pearson.

DeSantis, J. (2016). Investigating the relationship between TPACK and the ISTE standards for teachers. Issues and Trends in Educational Technology, 4(1), 16-30.

Durdu, L. \& Dag, F. (2017). Pre-Service teachers' TPACK development and conceptions through a TPACK-Based course. Australian Journal of Teacher Education, 42(11), 150-171. http://dx.doi.org/10.14221/ajte.2017v42n11.10

Ersoy, M., Yurdakul, I. K., \& Ceylan, B. (2016). Investigating preservice teachers' TPACK competencies through the lenses of ICT skills: An Experimental Study. Education and Science, 41(186), 119-135.

Ertmer, P. A. (2005). Teacher pedagogical beliefs: The final frontier in our quest for technology integration? Educational Technology Research and Development, 53(4), 25-39.

Ertmer, P. A., Ottenbreit-Leftwich, A. T., Sadik, O., Sendurur, E., \& Sendurur, P. (2012). Teacher beliefs and technology integration practices: A critical relationship. Computers \& Education, 59(2), 423-435

Flick, L. \& Bell, R. (2000). Preparing tomorrow's science teachers to use technology: Guidelines for Science educators. Contemporary Issues in Technology and Teacher Education, 1(1), 39-60.

Fraenkel, J. R. \& Wallen, N. E. (2006). How to design and evaluate research in education (6th ed.). New York: McGraw-Hill.

Galvis, H. A. (2012). Understanding beliefs, teachers' beliefs and their impact on the use of computer technology. Profile Issues in Teachers Professional Development, 14(2), 95112.

Gecer Kolburan, A. (2010). Experience of technical teacher candidates towards teaching technologies and material development course. Yuzuncu Yil University Journal of Education, 7(2), 1-25.

Gunduz, S. \& Odabasi, F. (2004). The importance of instructional technologies and material development course at pre-service teacher education in information age. The Turkish Online Journal of Educational Technology, 3(1), 7, 43-48.

Gokdas, I. \& Torun, F. (2017). Examining the impact of instructional technology and material design courses on technopedagogical education competency acquisition according to different variables. Educational Sciences: Theory \& Practice, 17(5), 1733-1758. 
Han, I., Shin, W.S., \& Ko, Y. (2017). The effect of student teaching experience and teacher beliefs on pre-service teachers' self-efficacy and intention to use technology in teaching. Teachers and Teaching, 23(7), 829-842.

Harris, J., Mishra, P. \& Koehler, M. J. (2009). Teachers' technological pedagogical content knowledge and learning activity types: Curriculum-based technology integration reframed. Journal of Research of Technology in Education, 41(4), 393-416.

Henson R. K. (2001). Teacher self-efficacy: substantive implications and measurement dilemmas. Retrieved on 11 April 2018 from http://files.eric.ed.gov/fulltext/ED452208. pdf on 15.12.2017.

Hew, K. \& Brush, T. (2007). Integrating technology into K-12 teaching and learning: Current knowledge gaps and recommendations for future research. Educational Technology Research and Development, 55(3), 223-252.

Hiebert, J., Morris, A.K., Berk, D., \& Jansen, A. (2007). Preparing teachers to learn from teaching. Journal of Teacher Education, 58(1) 47-61

Hoffer, M. \& Grandgenett, N. (2012). TPACK development in teacher education: A longitudinal study of preservice teachers in a Secondary M.Ed. program. Journal of Research on Technology in Education, 45(1), 83-106.

Hollins, E.R., Luna, C., \& Lopez, S. (2014). Learning to teach teachers. Teaching Education, 25(1), 99-124.

Incik, E. Y. \& Akay, C. (2017). A comprehensive analysis on technopedagogical education competency and technology perception of pre-service teachers: Relation, levels and views. Contemporary Educational Technology, 8(3), 232-248.

Ipek, C. \& Acuner, H. Y. (2011). Primary pre-service teachers' computer self-efficacy beliefs and attitudes toward educational technologies. Ahi Evran University Journal of Education, 12(2), 23-40.

Jang, S. J. \& Chen, K. C. (2010). From PCK to TPACK: Developing a transformative model for preservice science teachers. Journal of Science Education and Technology, 19(6), 553-564.

John, S. P. (2013). Influence of computer self-efficacy on information technology adoption. International Journal of Information Technology, 19(1) 1-13.

Kabakci-Yurdakul, I. (2011). Examining technopedagogical knowledge competencies of preservice teachers based on ICT usage. Hacettepe University Journal of Faculty of Education, 40, 397-408.

Kabakci-Yurdakul, I., Odabasi, H.F., Kilicer, K, Coklar, A.N., Birinci, G. \& Kurt, A.A. (2012). The development, validity and reliability of TPACK-deep: A technological pedagogical content knowledge scale. Computers \& Education, 58(3), 964-977.

Kabakci-Yurdakul, I. , Odabasi, H. F., Kilicer, K., Coklar, A. N. , Birinci, G. \& Kurt, A. A. (2014). Constructing technopedagogical education based on teacher competencies in terms of national standards. Elementary Education Online, 13(4), 1185-1202.

Karatas, I. (2014). Changing pre-service mathematics teachers' beliefs about using computers for teaching and learning mathematics: The effect of three different models. European Journal of Teacher Education, 37, 390-405. 
Karatas, F. I., \& Aslan Tutak, T. (2017). An examination of in-service secondary mathematics teachers' technological pedagogical content knowledge and their technology integration self-efficacy. Mustafa Kemal University Journal of Social Sciences, 14(37), 180-198.

Kay, R. H. (2006). Evaluating strategies used to incorporate technology into pre-service education: A review of the literature. Journal of Research on Technology in Education, 38(4), 383-408.

Kaya, Z. \& Yilayaz, O. (2013). Technology integration models in teacher education and technological pedagogical content knowledge. Western Anatolia Journal of Educational Sciences, 4(8), 57-83.

Keser, H., Karaoglan-Yılmaz, F. G. \& Yılmaz, R. (2015). TPACK Competencies and Technology Integration Self-Efficacy Perceptions of Pre-Service Teachers. Elementary Education Online, 14(4), 1193-1207.

Koehler, M. J. \& Mishra, P. (2008). Introducing TPCK in AACTE committee on innovation and technology: The handbook of technological pedagogical content knowledge (TPCK) for educators. New York: American Association of Colleges of Teacher Education and Routledge.

Koehler, M.J., Mishra, P., \& Yahya, K. (2007). Tracing the development of teacher knowledge in a design seminar: Integrating content, pedagogy and technology. Computers \& Education, 49, 740-762.

Kovalik, C., Kuo, C. L., \& Karpinski, A. (2013). Assessing preservice teachers' information and communication technologies knowledge. Journal of Technology and Teacher Education, 21(2), 179-202.

Kurz, T. L. \& Middleton, J. A. (2006). Using a functional approach to change preservice teachers' understanding of mathematics software. Journal of Research on Technology in Education, 39(1), 45-65.

Lee, Y., \& Lee, J. (2014). Enhancing pre-service teachers' self-efficacy beliefs for technology integration through lesson planning practice. Computers \& Education, 73, 121-128.

Lee, M. \& Tsai, C. (2010). Exploring teachers' perceived self-efficacy and technological pedagogical content knowledge with respect to educational use of the World Wide Web. Instructional Science: An International Journal of the Learning Sciences, 38(1), 1-21.

Lemon, N. \& Garvis, S. (2016). Pre-service teacher self-efficacy in digital technology. Teachers and Teaching, 22(3), 387-408.

Lucey, T.A. \& Grant, M.M. (2009). Ethical issues in instructional technology: An exploratory framework. Multicultural Education \& Technology Journal, 3(3), 196-212.

Ma, K. \& Cavangh, M. (2018). Classroom ready? Pre-service teachers' self-efficacy for their first professional experience placement. Australian Journal of Teacher Education, 43(7), 134151.

Mayes, R., Natividad, G., \& Spector, J.M. (2015). Challenges for educational technologists in the 21st century. Education Sciences, 5, 221-237.

Mazman, S. G. \& Usluel, Y. K. (2011). ICT integration into learning-teaching process: Models and indicators. Education Technology Theory and Practice. 1(1), 62-79.

MEB. (2017). Ministry of National Education. Ankara. 
Milner, R. \& Woolfolk-Hoy, A. (2002). Respect, social support and teacher efficacy: A case study. American Education Research Association, 26, 1- 10.

Mishra, P. \& Koehler, M.J. (2006). Technological pedagogical content knowledge: A framework for teacher knowledge. The Teachers College Record, 108(6), 1017-1054.

Nathan, E. J. (2009). An examination of the relationship between pre-service teachers' level of technology integration self-efficacy (TISE) and level of technological pedagogical content knowledge (TPACK) (Unpublished doctoral dissertation). University of Houston, Texas.

Pajares, M. F. (1992). Teachers' beliefs and educational research: Cleaning up a messy construct. Review of Educational Research, 62, 307-332.

Pajares (2002). Overview of social cognitive theory and of self-efficacy. Retrieved on 20 September 2018 from http://www.emory.edu/EDUCATION/mfp/eff.html

Parsons, M. \& Stephenson, M. (2005). Developing reflective practice in student teachers: Collaboration and critical partnerships. Teachers and Teaching: Theory and Practice, 11(1), 95-116.

Perkmen, S. \& Pamuk, S. (2011). Social cognitive predictors of pre-service teachers' technology integration performance. Asia Pacific Education Review, 12(1), 45-58.

Polly, D., Mims, C., Shepherd, C. E., \& Inan, F. (2010). Evidence of impact: Transforming teacher education with preparing tomorrow's teachers to teach with technology (PT3) grants. Teaching and Teacher Education, 26, 863-870.

Raphael, C. \& Mtebe, J. (2017). Pre-service teachers' self-efficacy beliefs towards educational technologies integration in Tanzania. Journal of Learning for Development, 4(2), 196-210

Ritzhaupt, A. D., Dawson, K., \& Cavanaugh, C. (2012). An investigation of factors influencing student use of technology in K-12 classrooms using path analysis. Journal of Educational Computing Research, 46(3), 229-254.

Ruggiero, D., \& Mong, C. J. (2015). The teacher technology integration experience: Practice and reflection in the classroom. Journal of Information Technology Education: Research, 14, 161-178.

Sari, A. A., Bilici, S. C., Baran, E., \& Ozbay, U. (2016). Investigating the relationship between teachers' technological pedagogical content knowledge (TPACK) competencies and attitudes towards information and communication technologies. Education Technology Theory and Practice, 6(1), 1-21.

Schoepp, K. (2005). Barriers to technology integration in a technology-rich environment: Learning and teaching in higher education. Gulf Perspectives, 2(1), 1-24.

Shin, S.K. (2015). Teaching critical, ethical and safe use of ICT in pre-service teacher education. Language Learning \& Technology, 19(1), 181-197.

Shin, T. S., Koehler M. Ji, Mishra P., Schmidt, D. A., Baran E. \& Thompson A. D. (2009, March). Changing technological pedagogical content knowledge (TPACK) through course experiences. Paper presented at the International Conference of the Society for Information Technology \& Teacher Education. Charleston, South Carolina.

Smith, K. B. \& Shotsberger, P. G. (2001). Web-based teacher education: Improving communication and professional knowledge in preservice and inservice teacher training. Retrieved on 11 April 2018 from http://www.eric.ed.gov/ERICDocs/data/ericdocs2sql/ content_storage_01/0000019b/80/19/7c/a1.pdf on 07.12.2017. 
Skaalvik, E. M. \& Skaalvik, S. (2010). Teacher self-efficacy and teacher burn put: A study of relations. Teaching and Teacher Education, 26, 1059-1069.

Sun, Y., Strobel, J., \& Newby, T.J. (2017). The impact of student teaching experience on preservice teachers' readiness for technology integration: A mixed methods study with growth curve modeling. Educational Technology Research and Development, 65(3), 597629.

Sweeney, T. \& Drummond, A. (2013). How prepared are our pre-service teachers to integrate technology? A pilot study. Australian Educational Computing, 27, 117-123.

Tabachnick, B. G. \& Fidell, L. S. (2001). Using multivariate statistics (4th Ed.). Needham Heights, MA: Allyn \& Bacon.

Tanak, A. (in press). Designing TPACK-based course for preparing student teachers to teach science with technological pedagogical content knowledge. Kasetsart Journal of Social Sciences. https://doi.org/10.1016/j.kjss.2018.07.012

Teo, T. (2009). Modeling technology acceptance in education: A study of pre-service teachers. Computers \& Education, 52(1), 302- 312.

Teo, T. (2011). Factors influencing teachers' intention to use technology: Model development and test. Computers \& Education, 57(4), 2432-2440.

Topuz, C. A. \& Goktas, Y. (2015). Projects for effective technology use in Turkish education system: Period of 1984-2013. International Journal of Informatics Technologies, 8(2) 99110.

Unal, E. (2013). An examination of the relationship between preservice teachers' perceptions of technology integration self-efficacy and technological pedagogical content knowledge competencies (Unpublished doctoral dissertation). Ankara University.

Vargas, O. L., Suárez, L. D., \& Ibáñez, J. I. (2017). Teacher's computer self-efficacy and its relationship with cognitive style and TPACK. Improving Schools, 20(3), 264-277.

Voogt, J. \& McKenney, S. (2017). TPACK in teacher education: Are we preparing teachers to use technology for early literacy? Technology, Pedagogy and Education, 26(1), 69-83, http://dx.doi.org/10.1080/1475939X.2016.1174730

Wang, L., Ertmer, P. A., \& Newby, T. J. (2004). Increasing pre-service teachers' self-efficacy beliefs for technology integration. Journal of Research on Technology in Education, 36(3), 231-250.

Yagci, M. (2016). Investigation of techno-pedagogical sufficiency of prospect pedagogical formation education teachers in terms of several variables. Journal of Kastamonu Education Faculty, 24(3), 1327-1342.

Yazar, T. (2015). Prospective teachers' opinions about instructional technologies and material design course. International Journal of Curriculum and Instructional Studies, 5(9), 23-34.

Yorulmaz, A., Can, S., \& Cokcaliskan, H. (2017). The Relationship between the Pre-service Classroom Teachers' Techno Pedagogical Instructional Competencies and Epistemological Beliefs. Journal of Education and Training Studies, 5(9), 27-35. https://doi.org/10.11114/jets.v5i9.2110

Zhang, P., \& Aikman, S. (2007). Attitudes in ICT Acceptance and use. In J. Jacko (Ed.), Humancomputer interaction, Part I (pp. 1021-1030). Berlin: Springer-Verlag. 
CONTEMPORARY EDUCATIONAL TECHNOLOGY, 2019, 10(1), 75-93

DOI: https://doi.org/10.30935/cet.512537 - TYPE: Research Article

Correspondence: Salih Birisci, Assistant Professor, Department of Computer Education and Instructional Technologies, Faculty of Education, Uludag University, Bursa, Turkey. 